\title{
Comparative Study of Two Nebulized Preparations of Salbutamol in Children
}

\author{
Samer Saadé, ${ }^{1 *}$ Alaa Hamieh, ${ }^{1}$ Paul-Henri Torbey ${ }^{2}$ \\ ${ }^{1}$ Department of Pediatrics, Hotel-Dieu de France Hospital, Beirut, Lebanon \\ ${ }^{2}$ Pediatric Pulmonology Unit, Department of Pediatrics, Hotel-Dieu de France Hospital, Lebanon
}

\begin{abstract}
Aim: Salbutamol is the main treatment for asthma attacks. It can be given via inhaler, nebulizer or oral route. Nebulization is mainly used at emergency departments. The aim of our study is to compare the clinical efficacy of two nebulized salbutamol preparations Ventolin ${ }^{\circledR}$ GSK and Asthalin ${ }^{\circledR}$ CIPLA.

Methods: We conducted a prospective double blind randomized trial between April and December 2017 in which 30 children with asthma were included. Children were assigned randomly to receive nebulized Asthalin ${ }^{\circledR}$ or Ventolin ${ }^{\circledR}$, with 15 patients included in each study arm. For each patient, oxygen saturation, presence of wheezing, retractions and thoraco-abdominal asynchrony, before and after Salbutamol nebulization were recorded. The effect of each treatment dose on oxygen saturation and respiratory rate after stratification of the initial population was analyzed.
\end{abstract}

Results: Ventolin ${ }^{\circledR}$ increased oxygen saturation by $1.87 \%$ and decreased respiratory rate by 10.87 breaths per minute, while Asthalin ${ }^{\circledR}$ improved oxygen saturation by $1.8 \%$ and decreased respiratory rate by 9.53 breaths per minute. However, the difference was not significant as it was not significant for respiratory symptoms improvement and need for oxygenation and hospitalization rates.

Conclusion: There is no significant difference between Ventolin ${ }^{\circledast}$ and Asthalin ${ }^{\circledast}$ when given via nebulization. Both treatments improved oxygen saturation, respiratory rate and respiratory symptoms similarly.

Keywords: asthma, salbutamol, respiratory rate, oxygen saturation, nebulization

\section{Introduction}

Salbutamol is a bronchodilator agent, which is the most widely used $\beta 2$-agonist for the treatment of asthma attacks. It is a racemic mixture of equal amounts of two enantiomers, (R)-salbutamol and (S)-salbutamol.1 The bronchodilator effects of salbutamol are attributed to (R)-salbutamol, while (S)-salbutamol is responsible of bronchospastic and pro-inflammatory effects. The chemical name of salbutamol is 1-(4-hydroxy-3-hydroxymethylphenyl)-2-(t-butylamino)-ethanol sulphate. Its molecular formula is $\left(\mathrm{C}_{13} \mathrm{H}_{21} \mathrm{NO}_{3}\right)_{2} \cdot \mathrm{H}$ $2 \mathrm{SO}_{4} .2$ Salbutamol stimulates $\beta 2$ adrenergic receptors in bronchial smooth muscle. It leads to the activation of enzyme adenyl cyclase that forms cyclic AMP (adenosine-mono-phosphate) from ATP (adenosine-tri-phosphate). High level of cyclic AMP triggers intracellular cascades ending in the release of potassium ions and decreased free intracellular calcium ions, which relaxes bronchial smooth muscle and decreases airway resistance. Salbutamol is the INN (international nonpropriety name) and albuterol is the USAN (United-States adopted name). It is marketed as Ventolin ${ }^{\circledR}$. Salbutamol generics are many: Asthalin ${ }^{\circledR}$, Proair $^{\circledR}$, Salamol $^{\circledR}$, Asmanil $^{\circledR}$, Asthacure ${ }^{\circledR}$ and others. Studies comparing the efficacy of Ventolin ${ }^{\circledR}$ and generic salbutamol found no evidence that generic salbutamol is less effective at relieving acute bronchoconstriction than Ventolin ${ }^{\circledR}$.3-6 In our experience at the pediatric emergency department (ER) of Hotel-Dieu de France, use of Asthalin ${ }^{\circledR}$ given via nebulization was feared to be less effective than previously used Ventolin ${ }^{\circledR}$, in terms of respiratory symptoms improvement, need of extra doses of nebulized Salbutamol and sometimes need for systemic corticosteroids. Our main objective was to compare the clinical efficacy of nebulized Ventolin ${ }^{\circledR}$ and Asthalin ${ }^{\circledR}$.

\footnotetext{
Quick Response Code:

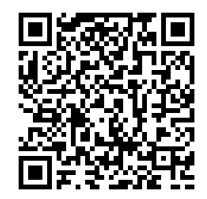
*Corresponding author: Samer Saadé, Hotel-Dieu de France, Achrafieh, Beirut, Lebanon Received: 16 September, 2020
Published: 10 October, 2020
Citation: Samer S, Alaa H, Pau HT. Comparative Study of Two Nebulized Preparations of Salbutamol in Children. SOJ Pedia Clin Neonato. 2020;1(1):1-5. DOI: 10.53902/SO- JPCN.2020.01.000501




\section{Materials and methods}

We conducted a prospective double blind randomized trial between April and December 2017 in which 30 children with asthma were included. Children were assigned randomly to receive nebulized Asthalin ${ }^{\circledR}$ or Ventolin ${ }^{\circledR}, 15$ patients were included in each study arm. An informed written consent was signed by the parents or the legal representative of the child. The approval of the Ethics committee was given on 6 April 2017. Inclusion criteria were the following: Children above 2 years of age presenting with expiratory dyspnea and wheezing or children below 2 years of age presenting for a third or more expiratory dyspnea. Children under 2 years of age who presented for their first or second episode of expiratory dyspnea were excluded. Demographic data of the children were recorded (age, sex). We recorded also data from child history such as history of expiratory dyspnea, treatment received before ER visit, chronic daily treatment at home, and history of hospitalization, ER visit or steroid use for expiratory dyspnea. Pulse oximetry via a General Electric V100 Dynamapwas used to measure transcutaneous oxygen saturation $\left(\mathrm{SpO}_{2}\right)$ for every child upon arrival to the ER. Children were assessed for respiratory rate (RR) at baseline, presence of wheezing, retractions, and thoraco-abdominal asynchrony. All children received a nebulized dose of $0.15 \mathrm{mg} / \mathrm{kg}$ of salbutamol along with $1 \mathrm{mg}$ Budesonide. Every dose was adjusted with the required volume of normal saline to achieve a total volume of 5 $\mathrm{ml}$ for children under $18 \mathrm{~kg}$ and $7 \mathrm{ml}$ for children over 18kg. Children received one or two doses of nebulized salbutamol depending on their response after first dose. Data recorded at baseline were recorded again 30 minutes after each dose. At the end, three outcomes measures were assessed: home discharge, hospitalization and need for oxygen therapy. Hypoxemia was defined as $\mathrm{SpO}_{2}$ below
93\% at baseline. Statistical analysis was done with XLSTAT 2015. According to every case, we used the Student test, the chi-square test and Mann-Whitney test.

\section{Results}

The Study included 17 boys ( 9 in the Ventolin ${ }^{\circledR}$ arm and 8 in the Asthalin ${ }^{\circledR}$ arm) and 13 girls (6 received Ventolin ${ }^{\circledR}$ and 7 received Asthalin ${ }^{\circledR}$ ). Average age in the Ventolin ${ }^{\circledR}$ arm was 51.4 months and 48.7 months in the Asthalin ${ }^{\circledR}$ arm. Among children receiving Vento$\operatorname{lin}^{\circledR}, 11(73.33 \%)$ needed a second dose while 13 children (86.66\%) needed a second dose in the Asthalin ${ }^{\circledR}$ group. Table 1 shows baseline $\mathrm{SpO}_{2}$ and modification after the first and second dose of Salbutamol. We noticed an improvement in $\mathrm{SpO}_{2}$ in $60 \%$ of children after the first dose of Ventolin ${ }^{\circledR}$ and in $50 \%$ of children who needed a second dose. Improvement was present in $53.33 \%$ of the children after the first dose of Asthalin ${ }^{\circledR}$ and in $53.8 \%$ for those who needed a second dose. Average global change in $\mathrm{SpO}_{2}$ noted with Ventolin ${ }^{\circledR}$ was a $1.87 \%$ improvement, while it was a $1.8 \%$ improvement with Asthalin ${ }^{\circledR}$. Detailed changes for each patient are presented in Table 2. Application of student test did not show a significant difference between the two groups with a p-value of 0.47 . Table 3 shows RR at baseline and after each dose of Ventolin ${ }^{\circledR}$ and Asthalin ${ }^{\circledR}$. Patients receiving Ventolin ${ }^{\circledR}$ showed decrease of RR in $80 \%$ of the cases after the first dose and in 50\% after the second dose versus $73.33 \%$ after the first dose of Asthalin ${ }^{\circledR}$ and $61.5 \%$ after the second dose. Average global decrease in the RR after one or two nebulizer sessions, was 10.87 breaths per minute with Ventolin ${ }^{\circledR}$ and 9.53 breaths per minute with Asthalin ${ }^{\circledR}$. Change in RR for the two treatments is shown in Table 4. Applying student test did not show a significant difference in these results, with a p-value of 0.32 .

Table 1: $\mathrm{SpO}_{2}$ at baseline and after each dose

\begin{tabular}{|c|c|c|c|c|c|c|}
\hline & \multicolumn{3}{|c|}{ Ventolin ${ }^{\circledR}$} & \multicolumn{3}{|c|}{ Asthalin ${ }^{\circledR}$} \\
\hline & Baseline $\mathrm{SpO}_{2}(\%)$ & $\mathrm{SpO}_{2}$ after first dose & $\begin{array}{c}\mathrm{SpO}_{2} \text { after second } \\
\text { dose }\end{array}$ & Baseline $\mathrm{SpO}_{2}(\%)$ & $\mathrm{SpO}_{2}$ after first dose & $\begin{array}{c}\mathrm{SpO}_{2} \text { after second } \\
\text { dose }\end{array}$ \\
\hline Patient 1 & 94 & 98 & $\mathrm{~N} / \mathrm{A}$ & 96 & 96 & 96 \\
\hline Patient 2 & 96 & 92 & 95 & 93 & 93 & 93 \\
\hline Patient 3 & 94 & 93 & 94 & 98 & 95 & 96 \\
\hline Patient 4 & 88 & 90 & 92 & 94 & 97 & $\mathrm{~N} / \mathrm{A}$ \\
\hline Patient 5 & 97 & 98 & $\mathrm{~N} / \mathrm{A}$ & 93 & 95 & 96 \\
\hline Patient 6 & 90 & 91 & 93 & 88 & 95 & 92 \\
\hline Patient 7 & 95 & 98 & $\mathrm{~N} / \mathrm{A}$ & 92 & 91 & 92 \\
\hline Patient 8 & 90 & 92 & 94 & 94 & 93 & 95 \\
\hline Patient 9 & 95 & 97 & 97 & 99 & 95 & 97 \\
\hline Patient 10 & 92 & 94 & 97 & 96 & 100 & 100 \\
\hline Patient 11 & 94 & 97 & 97 & 92 & 100 & $\mathrm{~N} / \mathrm{A}$ \\
\hline Patient 12 & 97 & 97 & 97 & 91 & 94 & 95 \\
\hline Patient 13 & 97 & 97 & 97 & 94 & 94 & 94 \\
\hline Patient 14 & 95 & 95 & $\mathrm{~N} / \mathrm{A}$ & 92 & 93 & 95 \\
\hline Patient 15 & 88 & 89 & 88 & 88 & 89 & 89 \\
\hline
\end{tabular}


Table 2: Change of $\mathrm{SpO}_{2}$ in each patient after one or two sessions of each treatment

\begin{tabular}{|c|c|c|}
\hline & $\mathrm{SpO}_{2}$ change after 1 or 2 sessions of Ventolin ${ }^{\circledR}(\%)$ & $\mathrm{SpO}_{2}$ change after 1 or 2 sessions of Asthalin ${ }^{\circledR}(\%)$ \\
\hline Patient 1 & 4 & 0 \\
\hline Patient 2 & -1 & 0 \\
\hline Patient 3 & 0 & -2 \\
\hline Patient 4 & 4 & 3 \\
\hline Patient 5 & 1 & 3 \\
\hline Patient 6 & 3 & 4 \\
\hline Patient 7 & 3 & 0 \\
\hline Patient 8 & 4 & 1 \\
\hline Patient 9 & 2 & -2 \\
\hline Patient 10 & 5 & 4 \\
\hline Patient 11 & 3 & 8 \\
\hline Patient 12 & 0 & 4 \\
\hline Patient 13 & 0 & 0 \\
\hline Patient 14 & 0 & 3 \\
\hline Patient 15 & 0 & 1 \\
\hline Average & 1.87 & 1.8 \\
\hline
\end{tabular}

Table 3: Respiratory rate at baseline and after each dose

\begin{tabular}{|c|c|c|c|c|c|c|}
\hline & \multicolumn{3}{|c|}{ Ventolin $^{\circledR}$} & \multicolumn{3}{|c|}{ Asthalin $^{\circledR}$} \\
\hline & $\begin{array}{l}\text { Baseline Respiratory } \\
\text { Rate (Breath/min) }\end{array}$ & $\begin{array}{l}\text { Respiratory Rate } \\
\text { after first dose }\end{array}$ & $\begin{array}{l}\text { Respiratory Rate } \\
\text { after second dose }\end{array}$ & $\begin{array}{l}\text { Baseline Respiratory } \\
\text { Rate (Breath/min) }\end{array}$ & $\begin{array}{l}\text { Respiratory Rate } \\
\text { after first dose }\end{array}$ & $\begin{array}{l}\text { Respiratory Rate } \\
\text { after second dose }\end{array}$ \\
\hline Patient 1 & 35 & 25 & $\mathrm{~N} / \mathrm{A}$ & 56 & 47 & 42 \\
\hline Patient 2 & 40 & 33 & 30 & 63 & 50 & 45 \\
\hline Patient 3 & 50 & 30 & 30 & 44 & 48 & 36 \\
\hline Patient 4 & 60 & 56 & 50 & 44 & 40 & $\mathrm{~N} / \mathrm{A}$ \\
\hline Patient 5 & 40 & 26 & $\mathrm{~N} / \mathrm{A}$ & 30 & 25 & 20 \\
\hline Patient 6 & 27 & 33 & 18 & 75 & 59 & 59 \\
\hline Patient 7 & 28 & 20 & $\mathrm{~N} / \mathrm{A}$ & 56 & 44 & 44 \\
\hline Patient 8 & 56 & 48 & 40 & 60 & 45 & 40 \\
\hline Patient 9 & 60 & 50 & 50 & 40 & 20 & 20 \\
\hline Patient 10 & 50 & 30 & 26 & 55 & 42 & 40 \\
\hline Patient 11 & 30 & 30 & 32 & 60 & 52 & N/A \\
\hline Patient 12 & 60 & 40 & 40 & 50 & 60 & 50 \\
\hline Patient 13 & 42 & 56 & 40 & 40 & 45 & 40 \\
\hline Patient 14 & 32 & 30 & $\mathrm{~N} / \mathrm{A}$ & 42 & 36 & 36 \\
\hline Patient 15 & 60 & 50 & 50 & 60 & 68 & 68 \\
\hline
\end{tabular}

Table 4: Change of respiratory rate in each patient after one or two sessions of each treatment

\begin{tabular}{|c|c|c|}
\hline & RR change after 1 or 2 sessions of Ventolin ${ }^{\circledR}$ & RR change after 1 or 2 sessions of Asthalin $^{\circledR}$ \\
\hline Patient 1 & -10 & -14 \\
\hline Patient 2 & -10 & -18 \\
\hline Patient 3 & -20 & -8 \\
\hline Patient 4 & -10 & -4 \\
\hline Patient 5 & -14 & -10 \\
\hline Patient 6 & -9 & -16 \\
\hline Patient 7 & -8 & -12 \\
\hline Patient 8 & -16 & -20 \\
\hline Patient 9 & -10 & -20 \\
\hline
\end{tabular}




\begin{tabular}{|c|c|c|}
\hline Patient 10 & -24 & -15 \\
\hline Patient 11 & 2 & -8 \\
\hline Patient 12 & -20 & 0 \\
\hline Patient 13 & -2 & 0 \\
\hline Patient 14 & -2 & -6 \\
\hline Patient 15 & -10 & 8 \\
\hline Average & -10.87 & -9.53 \\
\hline
\end{tabular}

All patients presented with wheezing to the ER. $40 \%$ showed normalization of their auscultatory findings after the first dose of Ventolin ${ }^{\circledR}$, and $66 \%$ of the remaining after the second dose. Global improvement of auscultation was $80 \%$. With Asthalin ${ }^{\circledR}$ we noted a normalization of auscultation in $13.33 \%$ of the patients after the first dose and in $69.2 \%$ after the second dose. Global improvement of auscultation was $73.33 \%$ with Asthalin ${ }^{\circledR}$. After applying the Chisquare test, we did not find a statistical difference neither after the first dose nor after the second, with respective p-values of 0.98 and 0.85 . Three patients (20\%) and four patients (26.66\%) had thoraco-abdominal asynchrony at baseline in the Ventolin ${ }^{\circledR}$ and Asthalin ${ }^{\circledR}$ group respectively. All of the 4 patients in the Asthalin ${ }^{\circledR}$ group were free of thoraco-abdominal asynchrony after first dose. Among patients receiving Ventolin ${ }^{\circledR}, 1$ (33.33\%) only showed slight improvement after the first dose and 2 (66.66\%) were free of asynchrony after the second dose. 14 patients $(93.33 \%)$ who received Ventolin ${ }^{\circledR}$ had retractions at baseline while all of the 15 patients who received Asthalin ${ }^{\circledR}$ had retractions. $42 \%$ of the children receiving Ventolin ${ }^{\circledR}$ showed improvement of retractions after the first dose, versus 33\% in the Asthalin ${ }^{\circledR}$ group. After the second dose, $80 \%$ of the patients receiving Ventolin ${ }^{\circledR}$ were better while $77 \%$ of patients receiving Asthalin ${ }^{\circledR}$ were better. However the difference was not significant, with a respective p-value of 0.59 and 0.85 after each dose, when applying the chi-square test.

In each group, one child needed oxygen therapy and 2 children needed hospitalization. Table 5 shows the children characteristics as for their previous history. $80 \%$ of the children who received
Ventolin ${ }^{\circledR}$ had a history of expiratory dyspnea, $40 \%$ received salbutamol at home before ER visit, $40 \%$ were taking daily controller treatment and $80 \%$ had a history of hospitalization, ER visit or steroid treatment for expiratory dyspnea. In children who received Asthalin $^{\circledR}, 86.66 \%$ had a history of expiratory dyspnea, $53.33 \%$ received salbutamol at home before ER visit, 53.33\% were taking chronic treatment and $93.33 \%$ had a history of hospitalization, ER visit or steroid treatment for expiratory dyspnea. Tables $6 \& 7$ show the difference of the effect of Ventolin ${ }^{\circledR}$ and Asthalin ${ }^{\circledR}$ respectively on $\mathrm{RR}$ and $\mathrm{SpO}_{2}$, after assigning the children who needed two doses of salbutamol to different subgroups. In the different subgroups that we studied, we found no statistical difference for the effect of Ventolin ${ }^{\circledR}$ and Asthalin ${ }^{\circledR}$ on RR and $\mathrm{SpO}_{2}$. Mann-Whitney test was used for the mentioned categories. Finally, for the group of patients presenting with hypoxemia, the average $\mathrm{SpO}_{2}$ improvement with Ventolin ${ }^{\circledR}$ was $3.2 \%$ while it was $3.33 \%$ with Asthalin ${ }^{\circledR}$. No statistical difference in $\mathrm{SpO}_{2}$ improvement between Ventolin ${ }^{\circledR}$ and Asthalin ${ }^{\circledR}$ after application of Student test, with a p-value of 0.46 .

Table 5: Classification of the patients according to their history and clinical presentation

\begin{tabular}{|c|c|c|}
\hline Number of patients with & Ventolin ${ }^{\circledR}$ & Asthalin ${ }^{\circledR}$ \\
\hline History of expiratory dyspnea & 12 & 13 \\
\hline Chronic treatment & 6 & 8 \\
\hline Treatment before ER visit & 6 & 8 \\
\hline $\begin{array}{c}\text { History of ER visit, hospitalization or } \\
\text { steroids use for expiratory dyspnea }\end{array}$ & 12 & 14 \\
\hline Retractions & 14 & 15 \\
\hline
\end{tabular}

Table 6: Comparative data between Ventolin ${ }^{\circledast}$ and Asthalin ${ }^{\circledR}$ effect on RR in the defined subgroups

\begin{tabular}{|c|c|c|c|c|}
\hline & U-value & Critical U-value at $p<0.05$ & Z-score & p-value \\
\hline History of expiratory dyspnea & 46 & 33 & 0.8 & 0.21 \\
\hline Chronic treatment & 15.5 & 6 & 0.24 & 0.4 \\
\hline History of ER visit, hospitalization or steroids use for expiratory dyspnea & 40 & 30 & 0.95 & 0.16 \\
\hline
\end{tabular}

Table 7: Comparative data between Ventolin ${ }^{\circledR}$ and Asthalin ${ }^{\circledR}$ effect on $\mathrm{SpO}_{2}$ in the defined subgroups

\begin{tabular}{|c|c|c|c|c|}
\hline & U-value & Critical U-value at $p<0.05$ & Z-score & p-value \\
\hline History of expiratory dyspnea & 53 & 33 & 0.33 & 0.37 \\
\hline Chronic treatment & 15.5 & 6 & 0.24 & 0.4 \\
\hline Treatment before ER visit & 11.5 & 6 & 0.89 & 0.19 \\
\hline History of ER visit, hospitalization or steroids use for expiratory dyspnea & 51 & 30 & 0.18 & 0.43 \\
\hline
\end{tabular}

\section{Discussion}

Beta2-adrenergic agonists delivered by inhalation are very widely used in asthma.7 The most common used beta2 adrenergic agonist is Salbutamol.8 It can be given via oral route, metered dose inhaler or nebulizer. There are few studies that compared the effect of Ventolin ${ }^{\circledR}$ to other Salbutamol generic inhalers, showing no significance difference according to the clinical effect.3-5 To our knowledge, this is the first study on the clinical difference between Asthalin ${ }^{\circledR}$ and Ventolin ${ }^{\circledR}$ when given via nebulization. The study was 
conducted after Asthalin was introduced to the ER at our institution and feared to lead to lesser improvement in asthmatic children clinical status. We excluded children with signs of bronchiolitis or under two years of age and presenting for their first or second expiratory dyspnea. These children usually may not respond to salbutamol.9 Children included in the study were diagnosed with asthma. Most of the children with expiratory dyspnea received at least two doses of nebulized Salbutamol. A single dose was administered only in case of frank improvement in $\mathrm{SpO}_{2}, \mathrm{RR}$, auscultation and respiratory distress features. Data in our study did not show significant difference between Ventolin ${ }^{\circledast}$ and Asthalin ${ }^{\circledR}$ in terms of improvement of $\mathrm{SpO}_{2}, \mathrm{RR}$, hospitalization, oxygen needs and clinical signs of respiratory distress. After stratification, we found that both treatments had similar effects in children with history of expiratory dyspnea or hospitalization, ER visit or recent corticosteroid use, in case of salbutamol use before ER visit or use of daily controller treatment.

Although evaluation of $\mathrm{SpO}_{2}$ and $\mathrm{RR}$ is an objective indicator of respiratory status, both of them may show spontaneous variability related to the dyspnea progression and not to the treatment received. This could explain the increase in the RR or the decrease in $\mathrm{SpO}_{2}$ after Salbutamol administration. Thus, this phenomenon may interfere with the evaluation of Salbutamol effect on dyspnea. On the other hand, assessment for the presence of retractions or thoraco-abdominal asynchrony and their severity may be altered by the subjectivity of the examiner. The volume of nebulization may have a direct effect on $\mathrm{SpO}_{2}$ by prolonging the time of nebulization and then the time of oxygen received. In fact, Asthalin ${ }^{\circledR}$ solution used contains $2.5 \mathrm{mg}$ per $2.5 \mathrm{ml}$ while Ventolin ${ }^{\circledR}$ solution contains $5 \mathrm{mg}$ per ml, which leads to a greater volume of Asthalin ${ }^{\circledR}$ solution needed to have the same dosage as Ventolin. In order to avoid this effect, we adjusted the volumes received by adding normal saline to achieve the same final nebulized volume. Nebulization volumes were 5 and $7 \mathrm{ml}$, according to children weight. We usually use Budesonide in our protocol to treat acute asthma. Budesonide dose was the same in both groups (1mg). Although Budesonide may have helped to improve the clinical status of the children presenting to ER, differences that could be observed are attributable to Salbutamol and not to Budesonide. Our study had some limitations. The main limitation was the relatively small number of patients included. The unicentric character of the study had a direct effect on the small sample size but offered the advantage of more uniform judgment of response. Patients in both groups were not matched according to their demographic data. As a result we could not compare the effect of demographic data on the response to either treatment.

\section{Conclusion}

We found that there is no significant difference between Ventolin ${ }^{\circledR}$ and Asthalin ${ }^{\circledR}$ when given via nebulization. Both treatments improved $\mathrm{SpO}_{2}$ and RR similarly. We observed the same rate of hospitalization and oxygen therapy after the use of both salbutamol preparations. Respiratory distress signs improved in both cases.

\section{References}

1. Medicinal Chemistry of the Peripheral Nervous System - Adrenergics and Cholinergic their Biosynthesis, Metabolism and Structure Activity Relationships. 2011.

2. Pubchem. Salbutamol. 2018.

3. Williamson IJ, Reid A, Monie RD, et al. Generic inhaled salbutamol versus branded salbutamol. A randomised double-blind study. Postgrad Med J. 1997;73(857): 156.

4. Pinto Pereira LM, Clement YN, Pinto Pereira SM. Comparison of innovator and generic salbutamol inhalers: a double-blind randomized study of efficacy and tolerance. Int J Clin Pharmacol Res. 2002;22(3-4): 73-80.

5. Frayh AA, Abba A, Isk A, et al. Establishing Therapeutic Bioequivalence of a Generic Salbutamol $\left(\right.$ Butalin $\left.^{\circledR}\right)$ Metered Dose Inhaler to Ventolin. Biomed Res. 2008; 19(1).

6. Catherina L Chang, Manisha Cooray, Graham Mills. Is Salamol less effective than Ventolin? A randomised, blinded, crossover study in New Zealand. N Z Med J. 2007;120(1267): U2874.

7. Walters EH, Walters J. Inhaled short acting beta2-agonist use in asthma: regular vs as needed treatment. Cochrane Database Syst Rev. 2000;(4): CD001285.

8. Barisione G, Baroffio M, Crimi E, et al. Beta-Adrenergic Agonists. Pharmaceuticals. 2010;3(4): 1016-44.

9. Schindler M. Do bronchodilators have an effect on bronchiolitis? Crit Care. 2002;6(2): 111-112. 